\title{
SAFETY OF FORMWORKS IN THE ENGINEERING AND GENERAL CONSTRUCTION SECTOR
}

\author{
doi: $\quad 10.2478 /$ czoto-2019-0037
}

Date of submission of the article to the Editor: 29/11/2018

Date of acceptance of the article by the Editor: 03/01/2019

\author{
Kinga Brózda ${ }^{1}$ - orcid id: 0000-0001-6346-1830 \\ Jacek Selejdak ${ }^{1}$ - orcid id: 0000-0001-9854-5962 \\ ${ }^{1}$ Czestochowa University of Technology, Poland, kbrozda@bud.pcz.pl, jselejdak@bud.pcz.pl
}

\begin{abstract}
Formwork systems are necessarily used in the implementation of the RC (reinforced concrete) structures. Formworks are required regardless of whether a construction is monolithic or prefabricated and used to form the engineering and general structures or structural elements, such as abutments, supports and decks of the bridges, tanks and retaining walls, but also industrial and accommodation facilities etc. Ensuring the OHS (occupational health and safety) during transport, assembly and disassembly of formworks is a necessary condition for the execution of RC works in a safe and economical way. The paper presents the analysis of the safety requirements for formworks. Furthermore, the general requirements for the execution of the formwork structures were discussed. The most common organizational and technological mistakes and cased of neglects related to the operation of the formwork which lead to infringement of the OHS regulations were also identified.
\end{abstract}

Keywords: occupational health and safety, civil engineering, reinforced concrete, formwork, requirements for formwork

\section{INTRODUCTION}

The approximate percent of the structures made using the concrete technology is estimated at $60-70 \%$ of all building and engineering structures (Ignatowski, 2008). Almost all of built structures or structural elements such as bridge supports (pillars or abutments), tunnels, high-rise buildings or hydrotechnical structures, including offshore structures, are made using the technology of the monolithic concrete, mainly as reinforced concrete $(\mathrm{RC})$ structures.

The universality of this technology is basically due to the several specific features such as free shaping the individual architectural form, very high durability of the constructions, the possibility of using advantageous static systems, and additional increased resistance of objects exposed to dynamic or even seismic effects (Orłowski, 2013). 


\section{FORMWORKS IN CIVIL ENGINEERING}

Almost every structure in the case of the technology of monolithic concrete construction is built directly on the building site. This means the necessity of using special forming devices, commonly called formwork, to shape individual concrete components (Jasiczak, 2003). The application of the formworks in the construction industry was first aimed to improve the implementation of concrete structures. This means in much easier and faster forming of monolithic concrete components. The next step in the development of the technology of monolithic concrete construction was the use of alternative forming devices such as stay-in-place (SIP) formworks, systemic formworks, and also slip-forming or self-climbing (SC) formworks (Jasiczak, 2003), (Wesołowska and Szczepaniak, 2012).

\subsection{General requirements}

In Poland, current solutions of the building formworks according to the Polish standard (PN-M-47850:1990), withdrawn without replacement, include the structure consisting of sheeting (or planning), fasteners, barring and supporting elements as horizontal braces, vertical posts or props, and supports. The formworks, understood as a specific type of temporary construction, are used to construct the concrete or RC structures. The main task is to ensure the desired shape of a concrete mixture, in accordance with the architectural and structural design, and maintaining the correct arrangement of the reinforcement during concreting, until the concrete mixture pouring process is completed and the required level of compressive strength of the concrete is reached (Brózda and Selejdak, 2018), (Orłowski, 2013). Another important requirement for formwork is to provide proper execution according to the design static model and standards such as (PN-90/M-47850:1990), (PN-EN 13670:2011), (PN-EN 1065:2001), (PN-M-47900-2:1996), (PN-M-47900-3:1996).

The main functions which building formwork should perform include (Piekarczyk et al., 2010; Johnston, 2008):

- to provide the safety of the structure during implementation and use, all of the load capacity conditions should have the appropriate safety factors;

- to ensure appropriate technical quality such as proper stiffness, placement and geometry of the formwork structure;

- to be economic in order to minimise the time and costs associated with the implementation, which is related to the effective execution of formwork.

The latter factor is especially important because the cost of the formwork (assembly, disassembly, the labour input of the workers etc.) ranges from $35 \%$ to $60 \%$ of the total cost of construction of concrete structures (Johnston, 2008). It is also associated with the kind of structural material from which the formwork is made since it is advisable to use materials with high strength and resistance, including high resistance to corrosion (Brózda and Selejdak, 2018; Lipinski, 2017; Radek et al., 2017).

\subsection{Organizational and technical mistakes}

The workers who construct the RC structures and consequently those who make formworks, often perform their work at heights. Therefore, it is extremely important to ensure proper protection for the workers against a life-threatening fall. Ensuring the OHS (occupational health and safety) and other safety regulations during transport, assembly and disassembly of formworks is an important responsibility for the 
execution of RC works (Szruba, 2016). If any infringements are detected in this area, all available means should be immediately used to remedy the problem. The most common technical and organizational mistakes are associated with marginalizing the necessity of using safety equipment. The particularly dangerous phenomenon include saving on health and safety equipment for economic reasons. This is a serious mistake, and savings resulting from such an approach can be very deceptive in the event of an accident at work (Ignatowski, 2011). Analysis of the most common organizational and technical mistakes should mostly focus on the mistakes due to incorrect selection of the type of formwork. Table 1 presents examples of such mistakes.

Table 1

The most common technical and organizational mistakes

\begin{tabular}{|c|c|c|}
\hline & $\begin{array}{c}\text { The mistakes } \\
\text { in the organizational sphere }\end{array}$ & $\begin{array}{c}\text { The mistakes } \\
\text { in the technical sphere }\end{array}$ \\
\hline 1. & $\begin{array}{l}\text { Removing the decision-making in the } \\
\text { area of formwork selection from people } \\
\text { directly involved in the construction } \\
\text { process. }\end{array}$ & $\begin{array}{l}\text { Too heavy formwork components (no } \\
\text { possibility to use construction cranes). }\end{array}$ \\
\hline 2. & Considering only economic aspects. & $\begin{array}{l}\text { Too many connecting components } \\
\text { which increase labour intensity. }\end{array}$ \\
\hline 3. & $\begin{array}{l}\text { Inadequate choice of the number of the } \\
\text { formwork components. }\end{array}$ & $\begin{array}{l}\text { The use of formwork systems without } \\
\text { safety equipment. }\end{array}$ \\
\hline 4. & $\begin{array}{l}\text { Choice of unsuitable formworks for } \\
\text { forming a complicated shape. }\end{array}$ & $\begin{array}{l}\text { Underestimating the values of the load } \\
\text { applied to the formwork. }\end{array}$ \\
\hline 5. & $\begin{array}{l}\text { Incorrect choice of the number of } \\
\text { workers or/and unqualified workers. }\end{array}$ & $\begin{array}{l}\text { Too high labour intensity during } \\
\text { assembly and disassembly of the } \\
\text { formwork. }\end{array}$ \\
\hline
\end{tabular}

Source: (Ignatowski, 2011).

\section{EFFECT OF FORMWORK ON OCCUPATIONAL SAFETY}

Safe construction work during building the RC structures should ensure protection of health, which is the one of the most fundamental human values. The chosen system should, above all, enable to construct all of the structural components, ensure efficient assembly and disassembly of the formwork and guarantee employee safety during the execution of works. Furthermore, almost $50 \%$ of the respondents (KrawczyńskaPiechna, 2016) rated the highest quality of the formed structure and the degree of safety of the works ensured during building the formworks as a criterion for the choice of the formwork system.

The attention should also be paid to the proper use of appropriate personal protective equipment. In the case of the absence of the possibility of using collective protective equipment, for example platforms, scaffolds, casings or nets, it is absolutely necessary to use personal protective equipment, such as safety harnesses, selfbraking devices, falling dampers etc. However, personal protective equipment is sometimes used improperly, for example, if the front of works with non-permanent workstations moves continuously. In such cases, the workers secured in this way interfere with each other during works, and the probability of an accident at work contrary to appearances - increases, which was examined and confirmed in other European Union countries (Ignatowski, 2011). 
Recently, a growing trend in the Polish construction industry to increase the level of safety of works in building sites can be noticed. The unification of internal procedures for health and life protection in large construction companies led to the implementation of advanced technical solutions which improved the safety of construction works. The growing awareness of construction companies which plan to use the technology of the RC works in a safe and economical way confirms that a high level of safety is not just an additional cost in the construction investment. The productivity of employees increases due to the improved sense of safety and comfortable working conditions. This helps employees not to pay particular attention to safety and possible risks and they can perform the construction works without worry (Arquillos at al., 2014).

\section{OHS REGULATIONS FOR FORMWORKS}

In Poland, the conditions and they way the concrete and $\mathrm{RC}$ works are executed, including the execution of the formworks, are determined by the following regulations:

- Journal of Laws 2003 No. 47 item 401;

- Journal of Laws 2005 No. 259 item 2170;

- Journal of Laws 2003 No. 169 item 1650 (as amended);

- Journal of Laws 2000 No. 26 item 313 (as amended).

According to the Article $237^{6}$ of the Polish Labour Code (Dz.U. 2018, item 917), the employer is obliged to provide the employee (free of charge) with personal protective equipment, protect them from dangerous and harmful factors occurring in the work environment, and inform them about the ways of using such equipment. The article also specifies that the personal protective equipment provided to the employee should meet the requirements for conformity assessment. It is worth mentioning that according to the Article $283 \S 1$ of the Polish Labour Code (Journal of Laws 2018 item 917), the employer who provides the employee with personal protective equipment that does not meet the requirements for conformity assessment is subject to a fine of 1,000 to 30,000 PLN.

Under the legal provisions, the contractor is responsible for selecting and using the appropriate collective or personal protective equipment. The contractor often decides on the use or non-use of protective measures and takes the risk of increasing the likelihood of accidents, which are often fatal. For this reason, the required safety and health protection plan plays a very important role (so-called BIOZ plan, in Polish: plan bezpieczeństwa i ochrony zdrowia).

The assembly and disassembly of formwork should be performed by appropriately skilled workers. The basic sources of OHS requirements in the assembly and disassembly of building formwork are Safety Instruction and Technical Instruction of the formwork that the formwork manufacturer is obliged to provide to the consumer. Furthermore, the construction site manager is obliged to familiarize the assembly workers with these Instructions, and then require meeting their provisions. Often, the companies which sell or rent the formworks offer training on assembly or disassembly of the formworks. The toolbox talk should be completed with a test of knowledge and skills of safe and technically correct assembly of the formwork, confirmed by a certificate of the course.

The selected occupational health and safety regulations listed in the acts presented in this Chapter regarding transport, assembly and disassembly of formworks include: 
- A danger zone should be designated around the installation site and fenced at a distance of at least $6 \mathrm{~m}$ from the outer projection line (contour) of the formwork;

- The components of the formwork should be prepared for transport in accordance with the manufacturer's factory-made packaging recommendations and be secured against moving due to inertia forces;

- Unloading should be performed using mechanical devices or manually so that the components do not cross, are not dropped or unloaded near the place where the formwork is installed;

- Clothing for assembly workers should be tight, comfortable and adapted to the employee's silhouette and conditions in which the work is performed. The assembly workers should be equipped with: protective helmet, non-slip footwear and protective gloves, and , if necessary, the equipment for work at heights;

- Work with adjustable ladders can be performed up to a height of $3 \mathrm{~m}$, while the assembly works at heights above $1 \mathrm{~m}$ may be performed by employees who have valid medical examinations;

- Assembly of the formwork should be made of mobile scaffoldings or from platforms designed for this purpose;

- If the working surface is located at a height of more than $1 \mathrm{~m}$, railings consisting of safety handrails placed at a height of at least $1.1 \mathrm{~m}$ and curbs with a height of at least $15 \mathrm{~cm}$ should be installed, while a crossbar should be placed between the handrail and the curb (in halfway up) or this space should be filled in other way that prevents from people falling out;

- If possible, the assembly of individual segments of the formwork should be carried out at zero level or on another surface on which safe assembly conditions can be ensured. Next, in order to lift the formwork segments, two identical slings of appropriate strength and length to ensure the opening angle of both slings (maximum $60^{\circ}$ ) should be used. Alternatively, a horizontal beam can be used for the same purpose, so-called spreader beam;

The use of formwork is acceptable after its acceptance by the construction site manager or an authorized person. This applies not only to the properties of the product but also to the materials used (Nowicka-Skowron and Ulewicz, 2015).

- The acceptance of the formwork should be confirmed by an entry in the construction logbook or in the technical acceptance report;

- Disassembly regulations are the same as those for assembly. It is not allowed to assemble or disassemble formworks at dusk without artificial lighting that ensures good visibility, during dense fog or heavy rain, during a storm and strong wind with a speed exceeding $10 \mathrm{~m} / \mathrm{s}$, and at places with black ice;

- The user is required to review and maintain the formwork after each use. Damaged components should be disassembled separately or repaired. It is also necessary to check its technical condition before re-using the formwork components.

Failure to comply with certain safety requirements and assembly procedures may result in severe accidents during assembly, operation or disassembly of formwork, and the material injuries as well. In case of any doubts about methods of assembly or disassembly of the formwork, the user should consult the service or the manufacturer of the formwork. 


\section{CONCLUSIONS}

Formwork systems are necessarily used during construction all of concrete or RC structures, regardless of whether it is monolithic or prefabricated. The formworks are used to form, support or in some cases reinforce entire structures or individual structural components, such as bridge abutments, supports and decks, tanks and retaining walls, and industrial and accommodation facilities etc. The compliance with the occupational health and safety regulations during transport, unloading, assembly, disassembly and usage of formworks is a necessary for the execution of concrete or $\mathrm{RC}$ works in a safe and economical way. Failure to comply with these safety requirements and manufacturer's assembly procedures may result in severe accidents, with are often fatal. This is also associated with legal liability of the construction site manager or other persons who are responsible for the proper conduct of construction works.

The safe execution of construction works is the most fundamental employee's value. High quality of the formed structure is as important as the degree of safety of the works to build the formwork. It is unacceptable to start the construction works the safety of workers is ensured. High standards of safety is not an additional cost in the construction investment, but it is the employer's main duty towards employees. Furthermore, the increased effectiveness of workers who have a sense of safety and comfortable working conditions was also confirmed.

\section{REFERENCES}

Arquillos, A.L., Rubio-Romero, J.C., Carrillo-Castrillo, J.A., 2014. Occupational Health and Safety (OHS) at construction projects. A perspective from formworks \& falseworks companies. International Symposium on Occupational Safety and Hygiene, Guimarães, Portugal, 43-47.

Brózda, K., Selejdak, J., 2018. Stay-in-Place Formworks Applied in Civil Engineering Requirements and Scope of the Control. Materials Research Proceedings, 5, 96100, DOI: $10.21741 / 9781945291814-17$

Dz.U. 2000 nr 26 poz. 313 - Rozporządzenie Ministra Pracy i Polityki Społecznej z dnia 14 marca 2000 r. w sprawie bezpieczeństwa i higieny pracy przy ręcznych pracach transportowych.

Dz.U. 2003 nr 169 poz. 1650 - Obwieszczenie Ministra Gospodarki, Pracy i Polityki Społecznej z dnia 28 sierpnia 2003 r. w sprawie ogłoszenia jednolitego tekstu rozporządzenia Ministra Pracy i Polityki Socjalnej w sprawie ogólnych przepisów bezpieczeństwa i higieny pracy.

Dz.U. 2003 nr 47 poz. 401 - Rozporządzenie Ministra Infrastruktury z dnia 6 lutego 2003 r. w sprawie bezpieczeństwa i higieny pracy podczas wykonywania robót budowlanych.

Dz.U. 2005 nr 259 poz. 2170 - Rozporządzenie Ministra Gospodarki z dnia 20 grudnia 2005 r. w sprawie zasadniczych wymagań dla maszyn i elementów bezpieczeństwa.

Dz.U. 2018 poz. 917 - Obwieszczenie Marszałka Sejmu Rzeczypospolitej Polskiej z dnia 13 kwietnia 2018 r. w sprawie ogłoszenia jednolitego tekstu ustawy - Kodeks pracy.

Ignatowski, P., 2008. Realizacja żelbetowych konstrukcji nowoczesnych budynków użyteczności publicznej. Materiały Budowlane, 6, 85-87. 
Ignatowski, P., 2011. Deskowania - najczęstsze błędy przy ich doborze, Inżynier budownictwa, 10, 82-86.

Jasiczak, J., 2003. Technologie budowlane II. Politechnika Poznańska, Wydział Budownictwa, Architektury i Inżynierii Środowiska, Instytut Konstrukcji Budowlanych, Poznań, Poland.

Johnston, D.W., 2008. Design and Construction of Concrete Formwork, in: E. G. Nawy (Ed.) Concrete Construction Engineering Handbook, CRC Press, Boca Raton, USA.

Krawczyńska-Piechna, A., 2016. Problem wyboru deskowania systemowego i propozycja jego rozwiązania, Inżynier Budownictwa, 11, 62-67.

Lipinski, T., 2017. Corrosion effect of $20 \% \mathrm{NaCl}$ solution on basic carbon structural S235JR steel. $16^{\text {th }}$ International Scientific Conference: Engineering for Rural Development, Jelgava, Latvia, 1069-1074, DOI: 10.22616/ERDev2017.16.N225

Nowicka-Skowron, M., Ulewicz, R., 2015. Quality management in logistics processes in metal branch, in: METAL 2015 - 24th International Conference on Metallurgy and Materials, Conference Proceedings, 1707-1712.

Orłowski, Z., 2013. Podstawy technologii betonowego budownictwa monolitycznego. Wydawnictwo Naukowe PWN, Warszawa, Poland.

Piekarczyk, A., Drobiec, Ł., Jasiński, R., 2010. Kontrola robót betonowych i żelbetowych $w$ trakcie wykonywania oraz kontrola odbiorcza. XXV Ogólnopolskie Warsztaty Pracy Projektanta Konstrukcji, Szczyrk, Poland.

PN-90/M-47850:1990. Deskowania dla budownictwa monolitycznego. Deskowania uniwersalne. Terminologia, podział i główne elementy składowe.

PN-EN 13670:2011. Execution of concrete structures (in Polish: Wykonywanie konstrukcji z betonu)

PN-EN 1065:2001. Adjustable telescopic steel props - Product specifications, design and assessment by calculation and tests (in Polish: Regulowane teleskopowe podpory stalowe - Charakterystyka, konstrukcja i ocena na podstawie obliczeń i badań.

PN-M-47900-2:1996. Rusztowania stojące metalowe robocze. Rusztowania stojakowe $z$ rur.

PN-M-47900-3:1996. Rusztowania stojące metalowe robocze. Rusztowania ramowe.

Radek, N., Pietraszek, J., Szczotok, A., 2017. Technology and application of electrospark deposited coatings. $26^{\text {th }}$ International Conference on Metallurgy and Materials, Brno, Czech Republic, 1432-1437.

Szruba M, 2016. Deskowania i rusztowania. Nowoczesne Budownictwo Inżynieryjne, 3-4, 64-67.

Wesołowska, M., Szczepaniak, P., 2012. Technologia deskowań traconych w budynkach energooszczędnych. Izolacje, 3, 26-29. 